\title{
Evaluating the Use of Multicultural-based Short Story Appreciation Textbook to Teach Prose-Fiction Appreciation Course
}

\author{
Muhamad Sholehhudin \\ Doctoral student of Sebelas Maret Surakarta State University, \\ em_sholehhudin@student.uns.ac.id
}

Herman J. Waluyo

Lecturer of Sebelas Maret Surakarta State University, hermanjwaluyo@staff.uns.ac.id

\section{Suyitno}

Lecturer of Sebelas Maret Surakarta State University, yit_suyitno52@yahoo.co.id

\section{Nugraheni Eko Wardhani}

Lecturer of Sebelas Maret Surakarta State University,

nugraheniekowardani_99@yahoo.co.id

The objectives of this research are (1) revealing the lecturers and students' perception on the use of multicultural-based short story appreciation textbook in teaching prose-fiction appreciation course; and (2) evaluating the effectiveness of multicultural-based short story appreciation textbook in teaching prose-fiction appreciation course. This study employed a mixed-method approach by combining evaluative descriptive research design and experimental design to evaluate multicultural-based short story appreciation textbook in private universities in East Java, Indonesia. The data were gathered via interview, questionnaires, documentation, and test. While choosing the experimental and control group from each university, the sampling technique used was cluster random sampling. The results reveal that both the lecturers and the students showed their positive responses and attitudes towards the use of multicultural-based short story appreciation textbook in teaching prose-fiction appreciation course. They asserted that the textbook could motivate the students in learning prose-fiction appreciation course. It is inferred that the use of multicultural-based short story appreciation textbook is more effective than the use of previously common textbook used by the lecturers to teach prose-fiction appreciation.

Keywords: short-story appreciation, multicultural-based textbook material, lecturers, and students' perception, textbook

Citation: Sholehhudin, M., Waluyo, H. J., Suyitno, \& Wadrhani, N. E. (2020). Evaluating the Use of Multicultural-based Short Story Appreciation Textbook to Teach Prose-Fiction Appreciation Course. International Journal of Instruction, 13(1), 831-844. https://doi.org/10.29333/iji.2020.13153a 


\section{INTRODUCTION}

A representative textbook for short story appreciation course is a mandatory requirement for lecturers and students of Indonesian Language Education Program. Teaching and learning activities that do not intensively integrate between textbooks of short story appreciation and students' competence will certainly impact on the students' learning outcomes. The real implication is that graduates are not skillful in teaching literary appreciation in schools. The problem is due to the scarcity of the suitable textbooks for short story appreciation used in universities. Besides, the quality of the existing textbooks used has not been able to answer global challenges, has not emphasized the theoretical element, and provide practical experience. An ideal textbook should have relevance and other non-technical functions. Answering these needs and gaps, there should be a textbook selection that can bridge the teaching competency needs in higher education context while also having a nurturing effect as a medium to inculcate awareness of thinking.

One of the most urgent and essential awareness of thinking that everyone should possess at present is about the importance of multiculturalism. The many of racial, ethnic, and religious issues (termed 'SARA' issues), conflicts of interest and radical notions that emerged in the last decade, are the evidence that nationalism is being challenged seriously. These problems can be increasingly widespread in other social domains if anticipatory actions do not become a shared agenda. Higher education, as one of the foremost fronts of the nation's progress, is considered capable of being an effective medium in yielding revolutionary thinking to overcome various problems. Multiculturalism should be chosen as the rationale that can produce solutions to various problems and social conflicts of the nation (Varshney, 2003). It is no exaggeration if multiculturalism is expected to be the main scheme of thought for the younger generation, especially at the level of higher education. Multiculturalism should be integrated into learning activities which can be done in various ways, one of which is through literary learning.

Literary learning is basically cannot be separated from the role of books, especially textbooks. Textbooks, as part of teaching materials in learning literary appreciation, are a pivotal part of learning. According to Tarigan (1986), a textbook is a standardized book specified in a particular field of study compiled by experts in that field for instructional purposes, which are equipped with easily understood teaching facilities by the users in schools and colleges so that they can support a teaching program. Textbooks, ideally, can be an appropriate alternative for good learning. The advantage of the textbook is that textbooks have high flexibility and the ability to summarize the theory and provide operational instructions as well by the goal of competencies (Fredericks, 2005).

Textbooks have a pivotal role in supporting the success of learning activities. The textbooks play an important part in the learning process, both as an independent source of learning for students and as an effective material for teachers in the development and presentation of study materials (Sheldon, 1988; Cunningsworth, 1995). The textbook can assist provide learners with data and autonomous teaching to enrich knowledge in 
teaching operations. In fact, the presence of educators' courses is helpful for teachers in enabling teaching, both in the presentation of materials and in the development of concepts and events.

The integration of multiculturalism in higher education is important to do because it is a strategic role to increase students' awareness of the importance of respecting diversity. Iwai (2013) conducted a study on multiculturalism integration in pre-service teachers. The study revealed the perceptions about multiculturalism and the issue of diversity among pre-service teachers through multicultural children's literature. A total of 19 preservice teachers as participants explored multicultural children's literature and joined classroom discussion for more than one semester. The research data was collected using pre-test and post-test Cultural Diversity Awareness Inventory (CDAI), open responses, quick writing, projects, and class interactions. The results showed an increase in participants' awareness of the issue of diversity and multiculturalism. They considered that it is important for students' development, and planned to implement it in their classes later.

Further, Santosa (2011) states that human's life is closely related to literary life. This implies that understanding multiculturalism to maintain diversity is important to be instilled through literary appreciation. Furthermore, multiculturalism can be used as another competency that is expected to be achieved in addition to the competence to appreciate literature. Specifically, in the short story appreciation, multiculturalism is expected to be able to enrich the short story appreciation experience while providing the provision of attitude in responding to diversity through multiculturalism.

By considering the technical and non-technical functions of the textbook, it would be very appropriate if the multicultural content is integrated into the short story appreciation activities. Various socio-cultural conditions in Indonesia require changes in views and attitudes that are appropriate to these conditions. It is expected that with the textbook of short story appreciation integrating multiculturalism, the awareness of maintaining diversity will be increasing.

However, in its efforts, there are still some obstacles to integrating the value of multiculturalism through literary appreciation activities, especially prose. The lecturers and students still do not have an awareness of the importance of understanding multiculturalism. Moreover, there is no textbook that specifically offers multiculturalism as an element that enriches experience in appreciation practice. The textbooks used in learning in higher education in Bojonegoro Region, for example, emphasize more on the theoretical aspects. The books include Theory of Literature (Rene Wellek \& Austin Warren), Pengantar Apresiasi Karya Sastra (Aminudin), Teori Pengkajian Fiksi (Burhan Nurgiyantoro) Memahami Cerita Rekaan (Panuti Sudjiman), Pengkajian dan Apresiasi Prosa Fiksi (Herman J. Waluyo). Most of the books discuss the theory of prose appreciation which focuses more on elements of the literary building, along with tips for appreciating prose. Based on this fact, a textbook for short story appreciation that can enrich the students' understanding of multiculturalism is urgently needed.

Textbooks of short story appreciation as an effort to strengthen the unity of the Indonesian nation should contain several elements of multiculturalism. In detail, Santosa 
(2011) summarizes a number of efforts that are able to shape multiculturalism in Indonesian literary appreciation-including short story appreciation, namely: (1) empowering the use of multilingualism in Indonesian language as a means of pronunciation of Indonesian literature, (2) cultural exploration sourced from Indonesian culture or local culture so that it shows the unity in diversity of ethnicity, religion and race, (3) the forecasting of the influence of multi-plural foreign cultures as a result of global culture, and (4) screening of modern culture, urban world, contemporary lifestyle, and advanced technology today, as a manifestation of the acceptance of globalization era and free markets or an antidote to global culture.

The ideology of multiculturalism is mostly appropriate to be taught to pre-service teachers who are expected to become professional teachers. Learning to appreciate short stories is expected to foster awareness of students as the next generation to uphold the value of diversity and wisely be able to obtain a simulation of the attitude of appreciation for diversity through short story appreciation activities. Due to the significant role of textbooks and the urgency of understanding the unity in diversity, the researchers chose to focus this study on equipping short story appreciation skills for students as prospective educators through the empowerment of multicultural short story appreciation textbooks.

\section{Research Questions}

From the background above, the researchers formulated the research questions as follows.

1. How do the perceptions of lecturers and students on the use of multicultural-based short story appreciation textbook in teaching prose-fiction appreciation course?

2. How is the effectiveness of multicultural-based short story appreciation textbook in teaching prose-fiction appreciation course?

\section{Research Objectives}

Based on the formulated research questions above, the objectives of the study are:

1. To explain the perceptions of lecturers and students on the use of multiculturalbased short story appreciation textbook in teaching prose-fiction appreciation course.

2. To reveal the effectiveness of multicultural-based short story appreciation textbook in teaching prose-fiction appreciation course.

\section{LITERATURE REVIEW}

\section{Short Story Appreciation}

The limitation of the term 'appreciation' basically has been explained by experts. According to Aminuddin (2011), the term 'appreciation' comes from Latin word appreciation, which means 'appreciate.' While Hornby (in Waluyo, 2011, p.29) states that appreciation comes from the English word 'appreciation' which means understanding, recognition, consideration, assessment, and a statement containing evaluation. Squire and Taba (in Aminuddin, 2011, p.34) state that as a process, appreciation involves three core elements, i.e. (1) cognitive aspects, (2) emotive aspects, 
and (3) evaluative aspects. Whereas, according to Gove (in Aminuddin, 2011, p.34), the term 'appreciation,' in a broader context, implies (1) recognition through inner feelings or sensitivity, and (2) understanding and recognition of the beauty values expressed by the author.

According to Dissick (in Waluyo and Wardhani, 2008, p.44), there are four levels of appreciation, i.e. (1) the level of interest, (2) the level of enjoyment, (3) the level of reacting, and (4) the level of production. In the level of interest, someone who likes to be involved in literature wants to read it, and if there is an appreciation program for literature, s/he wants to get involved or wants to watch it. The level of enjoyment means the level that indicates that a reader can be entertained by reading literary works. Reading literature is therefore a fun activity, not a burden. The level of reacting or giving a response is the level that shows someone being critical; s/he can assess a literary work based on certain criteria that can be accounted for. The level of production means that someone who appreciates literature has been able to carry out productive activities about literary works, for example writing literary works, reviewing literary works, making excerpts and summaries of literary works, poetry musicalization, drama performances, short story readings, etc.

Short story appreciation, as well as literary appreciation, is generally receptive and productive. Receptive appreciation is an appreciation that focuses on responding activities, which are mainly obtained through reading and listening activities. Productive appreciation is the appreciation of literary works that emphasize the creative process and creation. Specifically, in the short story respective appreciation, it can be in the form of reading short stories and listening to the reading of short stories while productive appreciation emphasizes writing activities (short story production, criticism, essays, reviews) and speaking (expressing opinions, reproducing) in connection with the results of short story appreciation (Aminuddin, 2011).

\section{Multiculturalism in Short Story Appreciation Textbooks}

The fundamental issue concerning the urgency of multicultural education has delivered this understanding into the substance of literature appreciation material, especially short stories. The strategic objectives of multicultural education, which is implicitly integrated into literary appreciation textbooks in universities should be able to solve the nation's problems.

The concept of multicultural education illustrates that there is no discrimination in education. Everyone has the right to get the same opportunity to improve their abilities according to their talents and interests through education. This is because multicultural education is essentially a concept of education that provides opportunities equitably to all students regardless of their ethnic, racial, religious, social class, and cultural characteristics (Banks, 2002, p.14). In line with this opinion, Zamroni (2011, p.140) states that multicultural education is a form of educational reform that aims to provide equal opportunities for all students regardless of their background so that all students can improve their abilities optimally according to their interests and talents.

Multicultural education can also be a strategic instrument for developing an awareness of one's pride in their nation. Andersen and Cusher (in Mahfud, 2014) state that 
multicultural education is defined as education about cultural diversity. Also, multicultural education is based on the fact that students do not study in emptiness; their culture influences them to learn in certain ways (Parkay and Stanford, 2010, p.35). In line with the opinion, Hernandez (in Mahfud, 2014, p.176) states that multicultural education is a perspective that recognizes the political, social and economic realities experienced by each individual in complex and diverse human encounters, and reflects the importance of culture, race, sexuality, and gender, ethnicity, religion, social and economic status in the education process.

Multicultural education has an important role in maintaining the diversity of cultures that exist in the Indonesian Nation. Zamroni (2011, p.156) suggests three main objectives of multicultural education that will be developed in each student. First, the development of cultural identity is a competency that students have to identify themselves with a particular ethnicity. These competencies include knowledge, understanding, and awareness of ethnic groups and create pride and confidence as citizens of certain ethnic groups. Second, interpersonal relations; it is the competence to make relations with other ethnic groups based on equality and avoiding suspicions and stereotypes. Third, is empowering oneself; it is an ability to develop continuously what is owned about multicultural life.

In the context of literary teaching, integrating multiculturalism in education can be applied in various activities, one of which is the appreciation of short stories. Appreciation of a multicultural short story means understanding different ethnic and intercultural diversity in the study and presentation of short stories. Short stories are literary products with a medium of language that specifically have an important role in multiculturalism. Ratna (2014, p.168) states that 'language plays an important role, even the most important in completing multiculturalism projects.' In other words, the language model, both primitive and modern, used by contemporary society clearly shows the multicultural nature, in which humans create the order of life more humane. In particular, she also explained that folklore, poetry, novels, dances, and so on could be used as a material in the teaching and learning process (2014, p.169).

In line with this understanding, short stories are one of the effective tools in promoting multi-culture in the context of learning in Indonesia. Short stories can be a means for increasing awareness of the importance of multiculturalism. In a short story, for example, various messages can be delivered in the form of interesting works to read and study. Some studies on the importance of multicultural literary appreciation had been conducted by Pentikainen (2012), Arellano (2011) which show that the appreciation of multicultural-based literature can foster a critical attitude towards the diversity of the nation. Another benefit of multicultural literary appreciation is teaching students to accept and understand racial, ethnic, and cultural differences through literary work. Ratna (2010, p.396) emphasizes that multiculturalism in literature will also be able to introduce cultural diversity so that it is also wealth for other collectivists.

By the explanation above, the appreciation of multicultural short stories can be understood as an effort to explore the values of multiculturalism in literary works, especially short stories. The effort to appreciate multicultural-based short stories will 
ultimately lead students to become sensitive and caring about various ethnic, social, cultural, and religious diversities.

\section{METHOD \\ Research Design}

This study combined evaluative descriptive design and experimental research design by following the mixed-method approach. The evaluative descriptive research design was used to describe the lecturers and students' perception toward the implementation of multicultural-based short story appreciation textbook in teaching prose-fiction appreciation course. Meanwhile, the experimental research design was used to test the effectiveness of multicultural-based short story appreciation textbook in teaching prosefiction appreciation course.

\section{Population and Sample}

The population of this study is a number of the third-grade students of the Indonesian Language Education Program of Private Universities in East Java with the total number of 300 students. Meanwhile, the sampling technique used was multi-stage random sampling. By using this kind of sampling technique, 64 students were obtained, they are 32 students from IKIP PGRI Bojonegoro and 32 students Darul Ulum Islamic University of Lamongan (UNISDA). Both universities have an almost similar condition. Besides, both universities are nationally accredited by the National Accreditation Board of Higher Education (BAN-PT) with 'B' Grade. Further, for revealing the perceptions of lecturers and students toward the implementation of multicultural-based short story appreciation textbook in teaching prose-fiction appreciation course, purposive sampling was employed to chose the sample from the two universities.

\section{Research Instruments}

\section{Documentation}

In this study, the preliminary data was taken from the results of students' daily test scores. This was done to find out the students' initial abilities about the appreciation of prose fiction in the short story material. These preliminary data are then analyzed using a $t$-test to find out whether the classes are in a balance condition. This balance test is important in experimental design. This process was carried out initially before the treatment was given to the experimental and control groups. This balance test was carried out to ensure that the increase of students' achievement is due to the treatment itself, not because of other factors such as different abilities between the two groups.

\section{Interview}

Interviews are used to gather as much information as possible, in-depth, and accurate, about the perceptions of lecturers and students toward the use of multicultural-based short story appreciation textbook in teaching prose-fiction appreciation course. The interview was addressed to the Head of the Study Program, lecturers of prose fiction appreciation (6 lecturers at once), and students (10 students who were chosen purposively). The interview protocol consisted of open questions related to the use of 
multicultural-based short story appreciation textbook in teaching prose-fiction appreciation course.

\section{Questionnaire}

Another instrument used to reveal the perceptions of lecturers and students of multicultural-based short story appreciation textbook in teaching prose-fiction appreciation course was questionnaire. This questionnaire was employed as a part of the triangulation of the results of the interview. A triangulation is needed in order to guarantee that the data yielded from this study are valid. The questions in this questionnaire were in the form of close-ended questions by following the Likert scale. The answer options for the questionnaire were ranged from strongly agree, agree, undecided, disagree, and strongly disagree. The model table of the questionnaire is presented as follows.

Table 1

The Model Table of Questionnaire

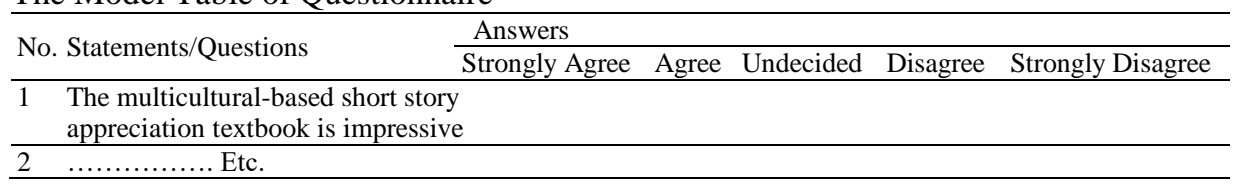

\section{Post test}

Post-tests were conducted to determine differences of students' abilities between the experimental group and the control group after the treatment. These post-tests were conducted to evaluate whether or not the use of multicultural-based short story appreciation textbook is more effective than the use of textbooks which were previously used in teaching prose-fiction appreciation course. In this post-test, researchers used multiple choices test. The multiple-choice questions instrument was first tried out in the non-sample class; then the results were analyzed for validity and reliability. After the instrument is statistically valid and reliable, then, it is ready to be used for the post-test (used to test students in the experimental and control groups after treatment)

\section{Validity and Reliability of the Instruments}

Validity and reliability are very important to determine the feasibility and usefulness of an instrument. Validity and reliability tests for interview protocols and questionnaire in this study were carried out through expert judgment, and all valid questions were stated. Meanwhile, the validity test for multiple-choice questions was carried out using the biserial point correlation coefficient (rpb), and the reliability test was carried out using the formula KR 20 (Kuder Ricardson). According to Stephanie (2016), KuderRichardson Formula 20, or KR-20, is a measure reliability for a test with binary variables (i.e. answers that are right or wrong). Dealing with multiple choice questions, it was found that there were 25 valid and reliable questions. The 25 questions, then, were used for the post-test

\section{Triangulation Technique}

As mentioned earlier, in this study, there were two types of data, namely, qualitative data and quantitative data. The qualitative data yielded from this study was also carried 
out triangulation to check the validity of the data. In this study, the triangulation process was carried out by comparing and analyzing the results of the questionnaire and the results of interviews.

\section{Research Procedures}

First, the researchers used the documentation of the results of the previous test scores to determine the students' initial conditions. In experimental design, samples, in this case, are experimental and control groups must have the same starting point (balance condition). After that, the researchers gave two different treatments to the two groups in teaching prose-fiction appreciation course. The experimental group was taught using multicultural-based short story appreciation textbook.

Conversely, the control group was treated by using previous textbooks that are commonly used by lecturers. After five meetings, the two groups were given a post-test. This post-test was intended to determine the effectiveness of multicultural-based short story appreciation textbook in teaching prose fiction appreciation course. After giving a post-test, the researchers also conducted interviews and distributed questionnaires to lecturers and students related to their responses and perceptions about the use of multicultural-based short story appreciation textbook.

\section{FINDINGS}

The perceptions of lecturers and students on the use of multicultural-based short story appreciation textbook in teaching prose-fiction appreciation course.

To reveal the perceptions of lecturers and students about the use of multicultural-based short story appreciation textbook in teaching prose fiction appreciation courses, researchers used two techniques, interview, and questionnaire. Based on the results of the questionnaire and interview to lecturers and students, the findings are divided into two, i.e., lecturers' perception and students' perception. First, the students' opinion of the multicultural-based short story appreciation textbook was that there is a new approach introduced by the textbook. The new approach is the integration of multicultural issues instilled in the textbook. Secondly, the textbook is very comprehensive since it contains both the theory and multicultural issue, so that the textbook does not only provide knowledge for students but also the critical issue to build their nationalism through multiculturalism. Third, students could meet their needs, and the new understandings included the urgency of multiculturalism towards educational activities. The respondents explained their opinion below.

"I support the appearance of multicultural issues and their problems as the material of discussion in our class. It has a solution for youth to build nationalism of our country. By using the books with the multicultural content, the students can use it as the knowledge/theory itself and also as the source of social discussion out

of the classroom. It can become an important approach in prose appreciations learning in Indonesia." (YN/R15).

From the explanation above, it can be inferred that the respondents were actively participated in the discussion forum, and also during the teaching process of Prose fiction Appreciation subject. The respondents stated the advantages of the book were that the students could use the material as the academic and non-academic purposes as 
well. Prose fiction Appreciation Textbook should meet the academic needs and creative needs. Other results show that the respondents agreed that multicultural understanding inspires them as pre-service teachers to conduct similar activities, integrating multiculturalism, in their future classes. This can be a means of self-upgrading for them.

"I like reading a short story. Moreover, after the lesson, I feel that the book of prose appreciation with a multicultural approach gives me a new experience. As the teacher in the future, I need to place the theory and master the practical way in appreciation. It will be a good mixing as the new approach of teaching and learning stuff. If I am good in prose appreciation and multicultural issues, I can be more confident to teach my future students" (AMY/R3)

One of the noticeable findings related to digitalization aspects is that the students suggested the e-book version or in another simple form. The book can be easily accessed directly, so it would be more flexible to use as the source of learning.

"I am a lazy student. It would be more interesting for me to reach the books in my hand. The conversion into an e-book or in the weblog is OK. I prefer reading on my gadget rather than opening the 'textbook.' I can learn easily. Not only in the classroom. So, the digital version would help me much." (TY/R10)

Overall, from the interview, it can be concluded that generally, the students agreed that the multicultural-based short story appreciation textbook could give advantages to prose fiction learning and it can help the students to be a good teacher at the future as well.

Specific findings of students' perception can be found in the questionnaire. The percentage of questionnaire filling resulted in followings. The students' impression of the multicultural-based short story appreciation textbook was on the average scale $(67 \%)$. The other $24 \%$ stated that it was well structured, and the rest $(9 \%)$ of respondents thought it was less structured. The readability aspect (layout, fonts, indent, spacing, and mechanical features) resulted that $78 \%$ of respondents were agreed that the book was good and readable, $15 \%$ stated it was average, and $7 \%$ respondents thought it was less readable.

The second perspective was the perspective of the lecturers, which figured other different perceptions of the book. Based on the interview, generally, they are openminded by the book. The lecturers agreed that the book could enrich their material and also their students' references.

"The basic needs of the student are enriching their reading experience by various kinds of short stories, so it would be good for them to use this book as the alternative ones. However, we should be a good facilitator who arranged what they should read or what they should not. So the book help students find a more trusted source to their study, instead of finding themselves by 'googling.' (SU/R2)

This book could be an alternative for the students to enrich their reading experience, especially the multicultural short stories as the source of appreciation practice. Besides, this book also helps lecturers to enrich their trusted literatures for the source of appreciation practice. Moreover, this book also could help students' understanding of multiculturalism. The following is the interview excerpt.

"I believe that the lecturers should develop their own need of their class and as much as possible provide relevancies of theories and literary products (esp. prose). 
This book tries to give them the experience of interacting with multisource of short stories. The multiculturalism issues are implicitly integrated through the materials. We should ask the students to find them." (STD/R.3)

The lecturers should be able to develop appropriate learning sources and materials for their classes. This book of multicultural-based short story appreciation could enrich the students' learning sources and materials. The multicultural short stories provided in the textbook could enlarge the students' knowledge in short story appreciation, especially to increase the understanding of multicultural values through short story appreciation activities. Besides, the students were enthusiastic in following the lessons. The students have a high interest and motivation. Also, when the students were asked to study in groups, based on instructions in the textbook, all group members played an active role. The students discussed short stories that were read from intrinsic elements.

The effectiveness of multicultural-based short story appreciation textbook in teaching prose-fiction appreciation course

\section{Preliminary data}

To find out the effectiveness of multicultural-based short story appreciation textbook, researchers used the $t$-test formula for analysis. Because this stage used experimental design, the condition of the students must be the same between the two groups, the experimental group, and the control group, before the treatment is carried out. To find out the initial conditions of students, researchers used documentation in the form of previous grades from students in a prose fiction appreciation course. The data are presented in the following table.

Table 2

Summary of Preliminary Data (Previous Data)

\begin{tabular}{llllll}
\hline Class & $\mathrm{N}$ & Mean & $\mathrm{S}^{2}$ & X Max & X Min \\
\hline Experimental & 32 & 61,64 & 130,96 & 78 & 40 \\
Control & 32 & 61,03 & 141,90 & 79 & 42 \\
\hline
\end{tabular}

The data, then, were tested for normality and homogeneity. The normality test used was the Lielifors formula and the homogeneity test used was the Bartlett formula. After that, the data was analyzed using a t-test for the balancing test. The results are presented in the following table.

Table 3

The Balancing Test

\begin{tabular}{llllll}
\hline$T$-test & Degree of Freedom & alpha & T-table & T-obs & Conclusion \\
\hline $\begin{array}{l}\text { Experiment and } \\
\text { control class }\end{array}$ & 62 & $1 \%$ & 1,670 & 0,139 & $\begin{array}{l}\text { Ho accepted (the } \\
\text { data is balance) }\end{array}$ \\
\hline
\end{tabular}

From table 2 above, it is clear that $t$-obs is lower than $t$-table. This means that there is no significant difference between the experimental group and the control group. In other words, the two groups are in a balanced condition and have the same starting point.

Post-test Data

After the two groups were treated using different treatments for five meetings, the two groups were then tested to find out receptive and productive abilities. The post-test results are presented in Table 3 below. 
Table 4

The Results of Post-Tests

\begin{tabular}{llllll}
\hline Class & $\mathrm{N}$ & Mean & $\mathrm{S}^{2}$ & $\mathrm{X} \max$ & $\mathrm{Xmin}$ \\
\hline Experimental & 32 & 70,79 & 93,86 & 89 & 52 \\
control & 32 & 66,16 & 130,27 & 83 & 44 \\
\hline
\end{tabular}

The data, then, were tested for normality and homogeneity. The normality test used was the Lielifors formula and the homogeneity test used was the Bartlett formula. After that, the data were analyzed using a t-test to test the hypothesis. The results are presented in the following table.

Table 5

Summary of the Hypothesis Testing

\begin{tabular}{llllll}
\hline$t$-test & Degree of Freedom & Alpha & T-table & T-obs & Conclusion \\
\hline Experiment and Control class & 62 & $1 \%$ & 1,670 & 1,806 & Ho is rejected \\
\hline
\end{tabular}

From table 4 above, it is clear that $t$-obs is higher than $t$-table. This means that there is a significant difference in students' achievement prose fiction appreciation course between the experimental group and the control group. The students in the experimental group achieved better than students in the control group. In conclusion, the use of multicultural-based short story appreciation textbook is more effective than textbooks that were previously used by lecturers in Prose Fiction Appreciation learning.

\section{DISCUSSION}

Based on the results of interview and questionnaire, learning prose fiction appreciation by using multicultural-based short story appreciation textbook can increase students and lecturers' motivation, active learning, and students' understanding of multiculturalism, especially in the Indonesian context. Studying prose fiction appreciation by using multicultural-based short story appreciation textbook can make time for learning to be efficient and make learning more effective because it contains special materials, i.e., multiculturalism, compared to textbooks that were previously used by lecturers. Hutchinson and Torres (1994) argue that teachers claim that text books can save time, provide direction for lessons, guide the discussion, facilitate homework, and make teaching easier, more organized, and more comfortable. Furthermore, Graves (2000) and Basturkmen (2010) also emphasize that one of the advantages of using textbooks is that it provides a set of visuals, activities, readings, etc., which can motivate students, can save teachers time in finding or developing material. Lecturers as a learning center in learning activities play an active role in determining the textbooks used in studying prose fiction appreciation course. Powell and Anderson (2002) show that the use of textbooks establishes a teacher-centered approach that plays a central role in lesson planning and the pace of progress. Meanwhile, Lecturer's attitude towards textbooks tends to have an impact on how they use it (McGrath, 2006).

The multicultural-based short story appreciation textbook is more effective than previous textbooks that have been used in teaching Prose Fiction Appreciation learning. This is evidenced by the results of the t-test. The multicultural-based short story appreciation textbook was developed based on multicultural short stories, which can enhance students' understanding of multicultural short stories. This book is effective 
because it mainly focuses on multicultural content, which is implemented in short story appreciation activities both in receptive and productive stages as well as multicultural short stories from national writers. It does not discuss too much theoretical knowledge that is too difficult to understand, such as general textbooks used by previous lecturers. Also, this book was developed based on students' needs and in line with the curriculum, syllabus, and lesson plans in the Indonesian Language Education Program. Before this textbook was made, a series of steps have been carried out, i.e., needs analysis, development stage, experts' assessment, limited trials, and large-scale experiments. That is why it is not surprising that this textbook is valid and reliable, and also effective for learning Prose Fiction Appreciation.

\section{CONCLUSION}

In conclusion, this study aimed at revealing the lecturers and students' perception on the use of multicultural-based short story appreciation textbook in teaching prose-fiction appreciation course; and evaluating the effectiveness of multicultural-based short story appreciation textbook in teaching prose-fiction appreciation course. The findings indicate that both lecturers and students from each university gave a positive response to the use of textbooks. They emphasized that textbooks can motivate students to study prose fiction appreciation course. Also, textbooks can help teachers to send material easily.

Furthermore, from the results of the t-test, it can be concluded that the use of multicultural-based short story appreciation textbook in teaching prose-fiction appreciation course is more effective than the use of previous general textbooks used by lecturers. These findings should be taken into account by the related parties while preparing and applying the right textbook materials to teach Prose Fiction Appreciation. However, this study is limited to the Indonesian context, especially the private universities in East Java context. For further studies, the larger population and sample and different context might be investigated.

\section{ACKNOWLEDGMENT}

This research was funded by the Indonesian Ministry of Research, Technology and Higher Education (Kemenristekdikti) through Doctoral Dissertation Research scheme in the year of 2018 .

\section{REFERENCES}

Aminuddin. (2010). Pengantar apresiasi karya sastra [The introduction of literary appreciation]. Bandung: Sinar Baru Algesindo.

Arellano, J. (2011). The use of multicultural literature in elementary classroom: Teaching acceptance and understanding of different races, ethnicities, and cultures. Retrieved from http://Citeseerx.ist.psu.edu/viewdoc/download?

Cunningsworth, A. (1995). Choosing your coursebook. Great Britain: Heinemann.

Fredericks, A. D. (2005). The complete idiot's guide to success as a teacher. Pennsylvania: Alpha.

Iwai, Y. (2013). Multicultural children literature and teacher candidates' awareness and attitudes toward cultural diversity. Int. E. J. of Elementary Education, 5(2), 185-198. 
Mahfud, C. (2014). Pendidikan multikultural [Multicultural education]. Yogyakarta: Pustaka Pelajar.

Nurgiyantoro, B. (2013). Penilaian pembelajaran bahasa berbasis kompetensi [Assessing competency-based language learning]. Yogyakarta: BPFE UGM.

Parkay, F. W., \& Sanford, B.H. (2010). Becoming a teacher. Pearson.

Pentikainen, J. (2012). The use of literature in developing multicultural sensitivity in teacher training. Procedia - Social and Behavioural Sciences, 45, 189-196.

Ratna, N. K. (2014). Peranan karya sastra, seni dan budaya dalam pendidikan karakter [The role of literary, art and cultural work in character education]. Yogyakarta: Pustaka Pelajar.

Richards, J. (2012). The role of textbooks in a language program. Retrieved from http://professorjackrichards.com/articles/role-of-textbooks/.

Santosa, P. (2011). Multikulturalisme sastra Indonesia modern memanfaatkan peran sastra Indonesia moderen dalam menghadapai budaya global [The multiculturalism of modern Indonesian literature by utilizing the role of modern Indonesian literature in facing global culture]. In Y. Maryani, \& S. R. H. Sitanggang (Eds.), Pemberdayaan Bahasa Indonesia memperkukuh budaya bangsa dalam era globalisasi: Risalah kongres Bahasa Indonesia VIII [Indonesian language empowerment to strengthen national culture in the era of globalization: The Indonesian Language Congress VIII] (pp. 384-401). Jakarta: Badan Pengembangan dan Pembinaan Bahasa.

Sheldon, L. E. (1998). Evaluating ELT textbook and materials. ELT J., 42(4), 237-246.

Stephanie. (2016). Kuder-Richardson 20 (KR-20) \& 21 (KR-21): What is the KuderRichardson 20? Retrieved from https://www.statisticshowto.datasciencecentral.com/kuder-richardson/.

Sukmadinata, N. S. (2007). Metode penelitian pendidikan [Educational research method]. Bandung: Remaja Rosdakarya.

Tarigan, H. G., \& Djago, T. (1986). Telaah buku teks Bahasa Indonesia [The review of Indonesian language textbook]. Bandung: Penerbit Angkasa.

Tomlinson, B. (Ed.). (2012). Material development in language teaching. Cambridge: Cambridge University Press.

Ur, P. (1996). A Course in language teaching. Cambridge: Cambridge University Press.

Varshney, A. (2003). Nationalism, ethnic conflict, and rationality. Perspectives on Politics, 1(1), 85-99.

Waluyo, H. J. (2011). Pengkajian dan apresiasi prosa fiksi [Prose fiction review and appreciation]. Surakarta: UNS Press

Waluyo, H. J., \& Nugraheni, E. W. (2008). Pengkajian cerita fiksi [The review of fictional story]. Surakarta: Widya Sari.

Zamroni, (2011). Pendidikan demokrasi pada masyarakat multikultural [Democratic education to multicultural society]. Yogyakarta: Gavin Kalam Utama. 